\title{
Innovative Technologies in Higher Education: Social Policy and Development of International Cooperation
}

\author{
Oksana Zhukova \\ V.N. Karazin Kharkiv National University \\ Oleksandr Kovalenko \\ Sumy State Pedagogical University Named After A.S. Makarenko \\ Olena Khil \\ Odessa National A.V. Nezhdanova Academy of Music \\ Liudmyla Ovsiankina \\ Borys Grinchenko Kyiv University
}

\begin{abstract}
The relevance of the study is conditioned by the possibilities of forming an international framework for the development of universities. The aim of the study was to identify all the factors that influence the quality of higher education. The novelty of the study is conditioned by the fact that the possibility of development for the university lies not only in the establishment of directed activities. The authors show that the possibility for the establishment of a macro-environment is achieved primarily by using tools for modelling the innovation environment in a university on a technological basis. In the course of a comparative analysis of the development of universities, the advantages and disadvantages of rating evaluation of universities were considered and the methods and results of leading rating agencies were analysed. It was found that ratings are an effective tool for managing the education system, a means of improving the competitiveness and quality of education, on the one hand, and an important source of information about the university for applicants.
\end{abstract}

Keywords: university, learning environment, structure, development strategy, rating

\section{INTRODUCTION}

The transformational shifts taking place in the global economy necessitate the creation of favourable conditions for innovative development. The implementation of the innovative development model requires the effective use of various forms of integration into the global educational space of Ukrainian educational institutions (Lafuente-Ruiz-De-Sabando et al., 2018). The dynamic change of technologies and the development of the information society require the provision of an appropriate level of higher education, which is determined, first and foremost, by the quality of educational services and the system of effective management of both individual higher educational institutions and the education system as a whole. That 
is why, to effectively manage the university, it is necessary to identify all the factors that affect the quality of higher education: directly involved in the transformation of the properties of the object, that is, the factors of influence and the conditions-forces that affect the object indirectly.

Analysing the environment for development of the competitive potential of the university, the following factors are identified that affect these processes: global (integration processes - the spread of the practice of transnational education); economic (decrease in real incomes of the population; high inflation; economic instability); socio-demographic (low standard of living of the population, insufficient level of development of social infrastructure; significant migration processes); respectively, types of economic activities (sufficiently high levels of qualifications and wages); market conditions of educational services (strengthening of market mechanisms; high level of competition among universities and university employees). They determine the factors that have a negative impact on the development of the innovative potential of higher education: low investment and innovation activity in the development of new high-tech technologies, lack of skills for commercialisation of scientific and technical developments; decline in the prestige of science, aging of scientific and scientific-pedagogical personnel; outflow of qualified scientific and scientific-pedagogical personnel to commercial structures and abroad; deterioration of the facilities and resources of education and science, etc. (Yonezawa, 2018). These factors reduce the scale of scientific research, weaken the ties of higher education institutions and scientific institutions of the education system with industry, the social sphere of the country, industry and academic science (Fiehe et al., 2014). The authors believe that the proposed list of factors requires systematisation and identification of groups of external and internal factors that affect the innovative activity of universities. In addition, the factor of the lack of public funding for innovation is highlighted (Veer Ramjeawon and Rowley, 2020).

The internal factors that favourably affect the development of the innovative climate of the university, include the following: high qualification of the teaching staff; rich traditions of the university in the field of organising the educational process, sports and cultural achievements; the presence of popular areas of training; the developed structure of education after graduation: doctoral studies, postgraduate studies, competition, dissertation councils for the defence of candidate and doctoral dissertations; an extensive network of branches; the presence of the potential of additional professional education; the availability of student practice bases; the provision of assistance in the employment of graduates by the higher educational institution; availability of monographs, textbooks and scientific and methodological developments published on the initiative of university; trends in the growth of scientific and technical developments (Howells et al., 2014; Karimova and Zhetpeisova, 2020; Serhiienko et al., 2021). The innovative orientation of the modernisation of higher education is largely determined by various factors of the external sociocultural environment. Among them: political (the presence of a targeted state order for the development and implementation of a state programme in the field of youth policy); economic (crisis phenomena in the economy); demographic (falling birth rate, family crisis, etc.); cultural and moral (moral degradation, a decrease in the level of general culture and education of young people); the growing importance of higher education in the world; the presence of competitors in the educational market. These factors together determine the development of an innovative climate in a particular university. This study suggests that the proposed list of factors needs to be systematised and clarified, since it is too cumbersome, which does not contribute to practical use in the management decision-making process (Henderson and Knott, 2015).

\section{MATERIALS AND METHODS}

Based on the analysis of the special economic literature, considering various aspects of the activities of universities, scientists pay attention to the factors that affect the object of their research (Barlas and Diker, 2000). Studying the influence of the external environment on the activities of higher education institutions, there is a need to distinguish five hierarchical infrastructures in the activities of business entities, including universities, and to relate to them the external environment, namely: international, national, regional, provincial, and local (Zabalandikoetxea and Merino, 2013; Mirke et al., 2019). Studying the influence of environmental factors on the activities of the university, in the macro-environment that surrounds the enterprise, there are significantly more factors than in the micro-environment. They are characterised by a 
high level of variability, uncertainty and unpredictability, which is due to their indirect effect on business entities (Davey and Tatnall, 2007). The main factors of the macro-environment include economic, political, socio-cultural, scientific and technological, natural and climatic, demographic, and the like (Contreras et al., 2015). Agreeing with the researcher above, this study suggests that these main factors certainly have an impact and are interrelated with the activities of the university.

Considering the factors that affect the competitiveness of the university, it is believed that the greatest impact on the competitiveness of the university is influenced by the following factors: scientific and educational potential, which has the greatest share among the assessments of scientists; resources and facilities; the available forms of training; the promotion of educational services in the market; the competitiveness of specialists trained by the university (Kirkland, 2008). The least influential are: the speed of response to changes in consumer requests, the range of educational services, the prestige of specialties, financial security and the internal corporate environment (Cameron and Klopper, 2015; Askhadullina et al., 2021). Among the internal factors that hinder or limit the creation of an innovative climate in the university, the following can be mentioned: the uncertainty of the criteria for selecting the content of education; the inconsistency of existing pedagogical technologies of teaching and control with modern requirements for the educational process and the quality of graduate training; the insufficient degree of development of fundamental and applied scientific research; the gap between theoretical training and practice; the weak receptivity of the teaching staff to innovations in various areas of improving the university's activities; the lack of an effective system for attracting students to research and development work (R\&D) and the use of research results in the educational process; the weak popularisation of the achievements of universities (scientific schools); the lack of state funding for the university's activities, insufficient development of resources and facilities, information and scientific and methodological support for the educational process, which is constantly being modernised; inefficiency of the current career guidance system; inconsistency of the level of the teaching staff with the requirements that are growing to the quality of student training; low salary of the teaching staff; aging of the teaching staff; lack of prestige of the university, etc. (Dumitrascu and Ciudin, 2015; Chaikin and Kirieieva, 2020).

Considering the factors that affect the effectiveness of scientific and innovative activities of universities, it is argued that the effective operation of higher education institutions as a whole and its scientific component is determined by many factors, among which the leading role is played by personnel, financial support and the introduction of innovative technologies (Han and Zhong, 2015). This approach is quite narrow and does not take into account external factors influencing the activities of the university, and the internal factors are covered in fragments.

\section{RESULTS AND DISCUSSION}

In the economic professional literature, the factors that influence the innovation activity of universities are classified according to the following characteristics (Leischnig and Geigenmüller, 2020): by the nature of the impact effectiveness (stimulating, restraining) and by the level of economic impact (external, internal). The study of the factors and conditions for ensuring the innovative development of higher education requires further research. Thus, before highlighting the essence of the factors that affect the innovative development of the university, it is worth determining what the term "factor" means (Kok et al., 2009). A factor is the driving force or cause of any process or phenomenon that determines its character or individual features (Pellow and Wilson, 1993). According to this interpretation, under the factors influencing the innovative development of the university, it is advisable to understand the conditions, the driving forces through which innovations are created and implemented in higher education (Valmorbida et al., 2015). All the many forces that influence the innovative development of higher education can be grouped into two classification groups: internal factors and external factors (Sánchez-Moreno and Toussaint-Banville, 2017). External factors are usually uncontrolled forces that influence managers' decisions and actions and, finally, the internal structure and processes in the organisation (Sharrock, 2012; Mokhlis et al., 2019). External factors that affect the activities and development of all business entities, including universities, have a number of features, in particular: 
- the specifics of the impact on the activities and development of the university arise independently of the activities of the higher educational institution;

- interdependence and interconditionality - the variability of one factor affects other factors;

- difficulty - a significant number of factors that significantly affect universities and a wide range of ways to influence its development;

- variability - a significant rate of change in the external environment of the functioning of universities;

- uncertainty - limited information and the variability of the environment of universities.

External factors that affect the innovative development of the university should be systematised into the following subgroups: financial and economic, technological, organisational and legal, political, demographic, socio-cultural, which will form an effective management system of the university, in addition, such a list of external factors combines factors of both direct and indirect influence (Figure 1).

Financial and economic factors reflect the level of economic development, innovation processes in the economic space, the state of the financial market, and the industry situation. This group of factors includes: the macroeconomic situation in the country, the volume of public spending on education, the development of non-state instruments for financing education, the level of financing of innovative projects, effective demand, the level of development of the market of educational services. Financial and economic factors, depending on the degree of their influence and trends of change, have a twofold impact on the process of making managerial decisions, that is, contributing to or hindering the innovative development of universities (Table 1). 


\section{FIGURE 1}

\section{EXTERNAL FACTORS THAT INFLUENCE THE INNOVATIVE DEVELOPMENT OF}

HIGHER EDUCATION INSTITUTIONS

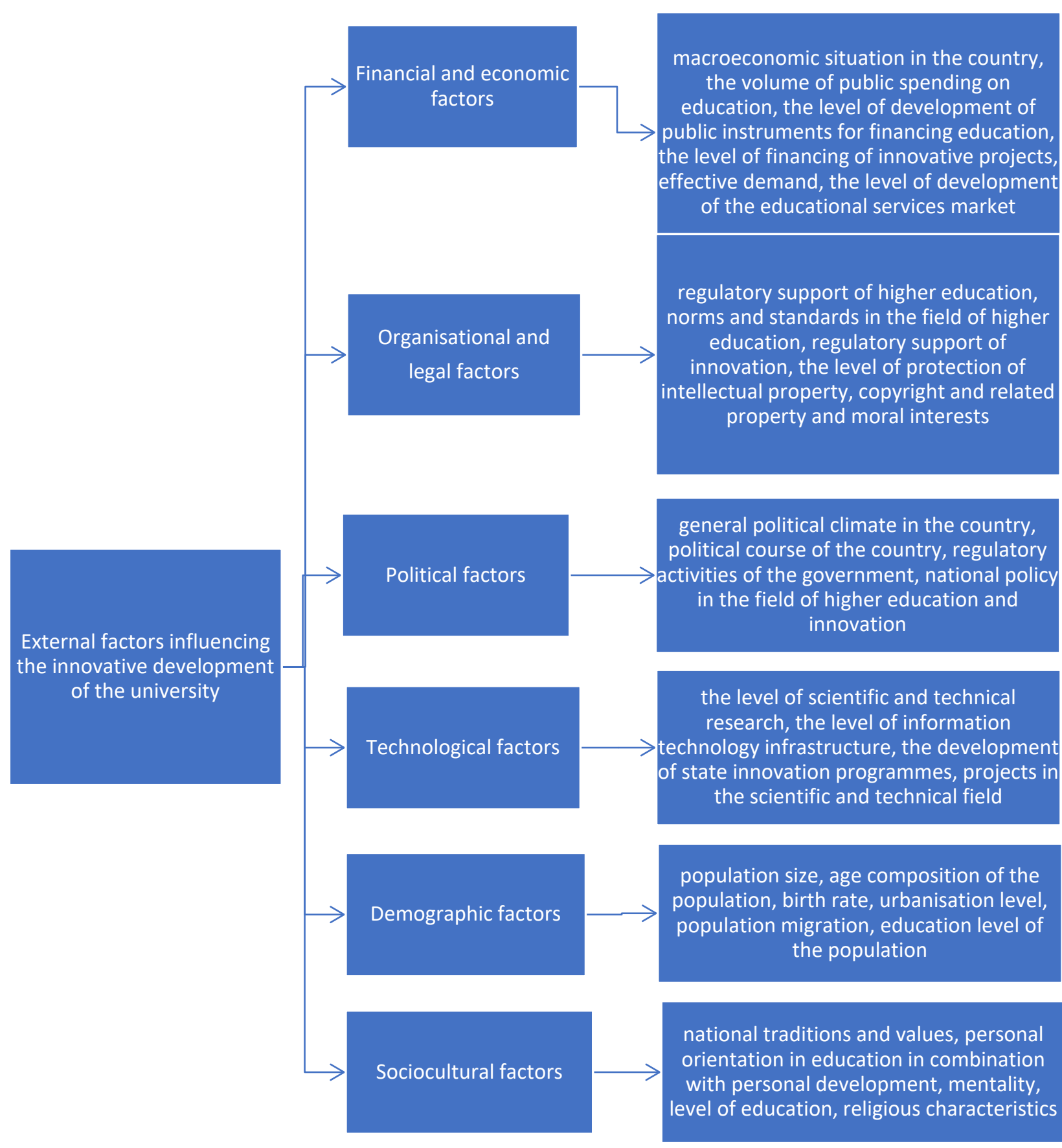


TABLE 1

INFLUENCE OF FINANCIAL AND ECONOMIC FACTORS ON THE INNOVATIVE DEVELOPMENT OF THE UNIVERSITY

\begin{tabular}{|c|c|c|c|}
\hline \multirow[t]{2}{*}{ Factor } & \multirow[t]{2}{*}{ Characteristics } & \multicolumn{2}{|c|}{$\begin{array}{c}\text { The nature of the influence of a factor on } \\
\text { the innovative development of the } \\
\text { university }\end{array}$} \\
\hline & & promotes & hinders \\
\hline \multirow{2}{*}{$\begin{array}{l}\text { The macroeconomic situation in the } \\
\text { country }\end{array}$} & stable & + & \\
\hline & unstable & & + \\
\hline \multirow{2}{*}{$\begin{array}{l}\text { The level of public spending on } \\
\text { education }\end{array}$} & low & & + \\
\hline & high & + & \\
\hline \multirow{2}{*}{$\begin{array}{l}\text { The level of development of non-state } \\
\text { educational financing instruments }\end{array}$} & low & & + \\
\hline & high & + & \\
\hline \multirow{2}{*}{$\begin{array}{l}\text { The level of financing of innovative } \\
\text { projects }\end{array}$} & low & & + \\
\hline & high & + & \\
\hline \multirow{2}{*}{ Effective demand } & increases & + & \\
\hline & decreases & & + \\
\hline \multirow{2}{*}{$\begin{array}{l}\text { The level of development of the } \\
\text { educational services market }\end{array}$} & low & & + \\
\hline & high & + & \\
\hline
\end{tabular}

Quite a significant influence on the innovative development of the university is carried out by organisational and legal factors, including: regulatory support for higher education; norms and standards in the field of higher education; regulatory support for innovation; the level of protection of intellectual property, copyright and related interests. Organisational and legal factors, depending on the degree of their impact, affect the management decision-making process in different ways, that is, they promote or hinder the innovative development of universities (Table 2).

TABLE 2

INFLUENCE OF ORGANISATIONAL AND LEGAL FACTORS ON THE INNOVATIVE DEVELOPMENT OF THE UNIVERSITY

\begin{tabular}{|c|c|c|c|}
\hline \multirow[t]{2}{*}{ Factor } & \multirow[t]{2}{*}{ Characteristics } & \multicolumn{2}{|c|}{$\begin{array}{c}\text { The nature of the influence of a factor on } \\
\text { the innovative development of the } \\
\text { university }\end{array}$} \\
\hline & & promotes & hinders \\
\hline \multirow{2}{*}{$\begin{array}{l}\text { Regulatory support of higher } \\
\text { education }\end{array}$} & efficient & + & \\
\hline & inefficient & & + \\
\hline \multirow{2}{*}{$\begin{array}{l}\text { Norms and standards in the field of } \\
\text { higher education }\end{array}$} & perfect & + & \\
\hline & imperfect & & + \\
\hline \multirow{2}{*}{$\begin{array}{l}\text { Regulatory support of innovation } \\
\text { activities }\end{array}$} & efficient & + & \\
\hline & inefficient & & + \\
\hline \multirow{2}{*}{$\begin{array}{l}\text { The level of protection of intellectual } \\
\text { property, copyright and related } \\
\text { interests }\end{array}$} & significant & + & \\
\hline & insignificant & & + \\
\hline
\end{tabular}

Political factors that influence the innovative development of the university, according to the authors of the article, are: the general political climate in the country; the political course of the country; regulatory activities of the government; national policy in the field of higher education and innovation. Political 
factors, depending on the degree of their impact, affect the process of management decision-making in different ways, that is, they promote or hinder the innovative development of universities (Table 3 ).

TABLE 3

INFLUENCE OF POLITICAL FACTORS ON THE INNOVATIVE DEVELOPMENT OF THE UNIVERSITY

\begin{tabular}{|c|c|c|c|}
\hline \multirow[t]{2}{*}{ Factor } & \multirow[t]{2}{*}{ Characteristics } & \multicolumn{2}{|c|}{$\begin{array}{c}\text { The nature of the influence of a factor on } \\
\text { the innovative development of the } \\
\text { university }\end{array}$} \\
\hline & & promotes & hinders \\
\hline \multirow{2}{*}{ General political climate in the state } & favourable & + & \\
\hline & unfavourable & & + \\
\hline \multirow{2}{*}{ The political situation in the country } & stable & + & \\
\hline & unstable & & + \\
\hline \multirow{2}{*}{$\begin{array}{l}\text { Regulatory activities of the } \\
\text { government }\end{array}$} & strict & & + \\
\hline & liberal & + & \\
\hline \multirow{2}{*}{$\begin{array}{l}\text { National policy in the field of higher } \\
\text { education and innovation activities }\end{array}$} & progressive & + & \\
\hline & conservative & & + \\
\hline
\end{tabular}

Technological factors are associated with the development of equipment, technologies, and tools that are used both during the management of the university and during the organisation of the educational process. In addition, technological factors include the level of scientific and technical research, the level of information and technological infrastructure, the development of state innovation programmes, scientific and technical projects. Financial and economic factors, depending on the degree of their influence and trends, have a twofold impact on the process of making managerial decisions, that is, promoting or hindering the innovative development of universities (Table 1).

TABLE 4

INFLUENCE OF TECHNOLOGICAL FACTORS ON THE INNOVATIVE DEVELOPMENT OF THE UNIVERSITY

\begin{tabular}{|l|c|c|c|}
\hline \multirow{2}{*}{ Factor } & \multirow{2}{*}{ Characteristics } & \multicolumn{2}{c|}{$\begin{array}{c}\text { The nature of the influence of a factor on } \\
\text { the innovative development of the } \\
\text { university }\end{array}$} \\
\cline { 3 - 4 } & & hromotes & hinders \\
\hline \multirow{2}{*}{$\begin{array}{l}\text { Level of scientific and technical } \\
\text { research }\end{array}$} & high & + & + \\
\hline \multirow{2}{*}{ Level of technology development } & high & + & + \\
\cline { 2 - 4 } $\begin{array}{l}\text { Level of development of the } \\
\text { information technology infrastructure }\end{array}$ & low & & + \\
\hline $\begin{array}{l}\text { Availability of state innovation } \\
\text { programmes, projects in the scientific } \\
\text { and technical field }\end{array}$ & high & + & + \\
\cline { 2 - 4 } & availability & + & + \\
\hline
\end{tabular}

The main demographic factors that have a significant impact on the innovative development of the university are: population size, age composition of the population, birth rate, level of urbanisation, migration of the population, income level of the population. Demographic factors, depending on the degree 
of their impact, affect the management decision-making in different ways, that is, they promote or hinder the innovative development of universities (Table 5).

\section{TABLE 5 \\ INFLUENCE OF DEMOGRAPHIC FACTORS ON THE INNOVATIVE DEVELOPMENT OF THE UNIVERSITY}

\begin{tabular}{|l|c|c|c|}
\hline \multirow{2}{*}{ Factor } & \multirow{2}{*}{ Characteristics } & \multicolumn{2}{c|}{$\begin{array}{c}\text { The nature of the influence of a factor on } \\
\text { the innovative development of the } \\
\text { university }\end{array}$} \\
\cline { 3 - 4 } & & promotes & hinders \\
\hline \multirow{2}{*}{ Population size } & high & + & + \\
\hline \multirow{2}{*}{ Age structure of the population } & low & & + \\
\hline \multirow{2}{*}{ Birth rate } & high & & + \\
\hline \multirow{2}{*}{ Level of urbanisation } & high & + & + \\
\hline \multirow{2}{*}{$\begin{array}{l}\text { Educational migration of the } \\
\text { population }\end{array}$} & low & & + \\
\hline \multirow{2}{*}{ Income level of the population } & high & + & + \\
\cline { 2 - 4 } & low & & + \\
\cline { 2 - 4 } & insignificant & + & + \\
\cline { 2 - 4 } & high & + & + \\
\hline
\end{tabular}

Sociocultural factors are formed within a particular society and reflect the views, values and norms of behaviour of people, which affects decision-making. Socio-cultural factors include: national traditions and values; personal orientation in education in combination with personal development; mental characteristics of the nation; educational level; religious characteristics. Sociocultural factors have a significant impact on the development of the education system as a whole, as well as on the activities of universities and their innovative development, as well as on the individual's behaviour model. For example, today many universities in the Islamic countries have lost their leading scientific role, faced with a number of problems. Firstly, it is worth noting that the situation in different Islamic countries is ambiguous. In Syria, Lebanon, and Egypt, for example, the education system is similar to that of Europe. Schools in these countries are divided into primary, secondary, and higher institutions. Primary school education (lower secondary education) is compulsory. The twelfth grade ends with exams, the number of points determines the range of universities available to the applicant for admission.

The highest percentage of points is required by the medical university (at least $98 \%$ ), followed by engineering (about 90\%). Internships, post-graduate studies, and doctoral studies are also arranged according to the Western standards. However, in the countries located to the south, regardless of the level of the country's economy, the situation in education is rather complicated. Thus, if in Egypt the percentage of uneducated people is 20\%, then in the Arabian Peninsula it is higher - about 40-50\%. In these countries, for example, in Saudi Arabia, almost no attention is paid to teaching exact sciences, the history course covers only the history of Islamic countries and conquests. The educational policy in the Kingdom of Saudi Arabia is completely derived from Islam, interpreted as "the faith of a nation that represents its teachings, its profession, its morals, as well as its true path, system of power and, in general, a comprehensive system of life values". Therefore, the study of Islamic culture is the keystone throughout all the years of study in higher educational institutions.

Another trend is the decrease, and sometimes the lack of interest of the younger generation in getting an education, improving their cultural and intellectual level. And this is despite the fact that in the Arab region, more than $60 \%$ of the population is represented by people under the age of 30 . In many oil-producing 
countries, significant success has been achieved in the field of education and science. For example, in the UAE, spending on education ranks second in the federal budget after defence. The law provides for compulsory secondary education lasting 12 years, which meets the requirements of European standards. All levels of education, including higher education, are free for citizens, regardless of the location of the university chosen by the student. In the UAE, women make up more than $75 \%$ of university students, which is the highest rate in the world. Socio-cultural factors, depending on the degree of their impact, affect the management decision-making in different ways, that is, they promote or hinder the innovative development of universities (Table 6).

TABLE 6

\section{THE INFLUENCE OF SOCIO-CULTURAL FACTORS ON THE INNOVATIVE DEVELOPMENT OF THE UNIVERSITY}

\begin{tabular}{|c|c|c|c|}
\hline \multirow{2}{*}{ Factor } & \multirow{2}{*}{ Characteristics } & $\begin{array}{c}\text { The nature of the influence of a factor on } \\
\text { the innovative development of the } \\
\text { university }\end{array}$ \\
\cline { 3 - 4 } & & promotes & hinders \\
\hline National traditions and values & & + & + \\
\hline Educational level & high & + & + \\
\cline { 2 - 4 } & low & & + \\
\hline $\begin{array}{c}\text { Personal orientation in education in } \\
\text { combination with personal } \\
\text { development }\end{array}$ & & + & + \\
\hline Mental characteristics of the nation & & + & + \\
\hline Religious specifics & & + & + \\
\hline
\end{tabular}

Internal factors are factors that are directly related to the performance of a business entity, that is, in accordance with the object of this study, a higher educational institution. External factors that affect the activities and development of all business entities, including universities, have a number of features, in particular:

- specifics of the impact on the activities and development of the university - arise as a result of the activities of the university and affect it;

- conditionality - changes in environmental factors affecting internal factors;

- interdependence - a change in one factor causes a change in others;

- relative ease of accounting.

Internal factors that affect the innovative development of the university should be grouped into the following subgroups: financial and economic, organisational and legal, scientific and technological, managerial, personnel (Figure 2). 


\section{FIGURE 2 \\ INTERNAL FACTORS INFLUENCING THE INNOVATIVE DEVELOPMENT OF THE UNIVERSITY}

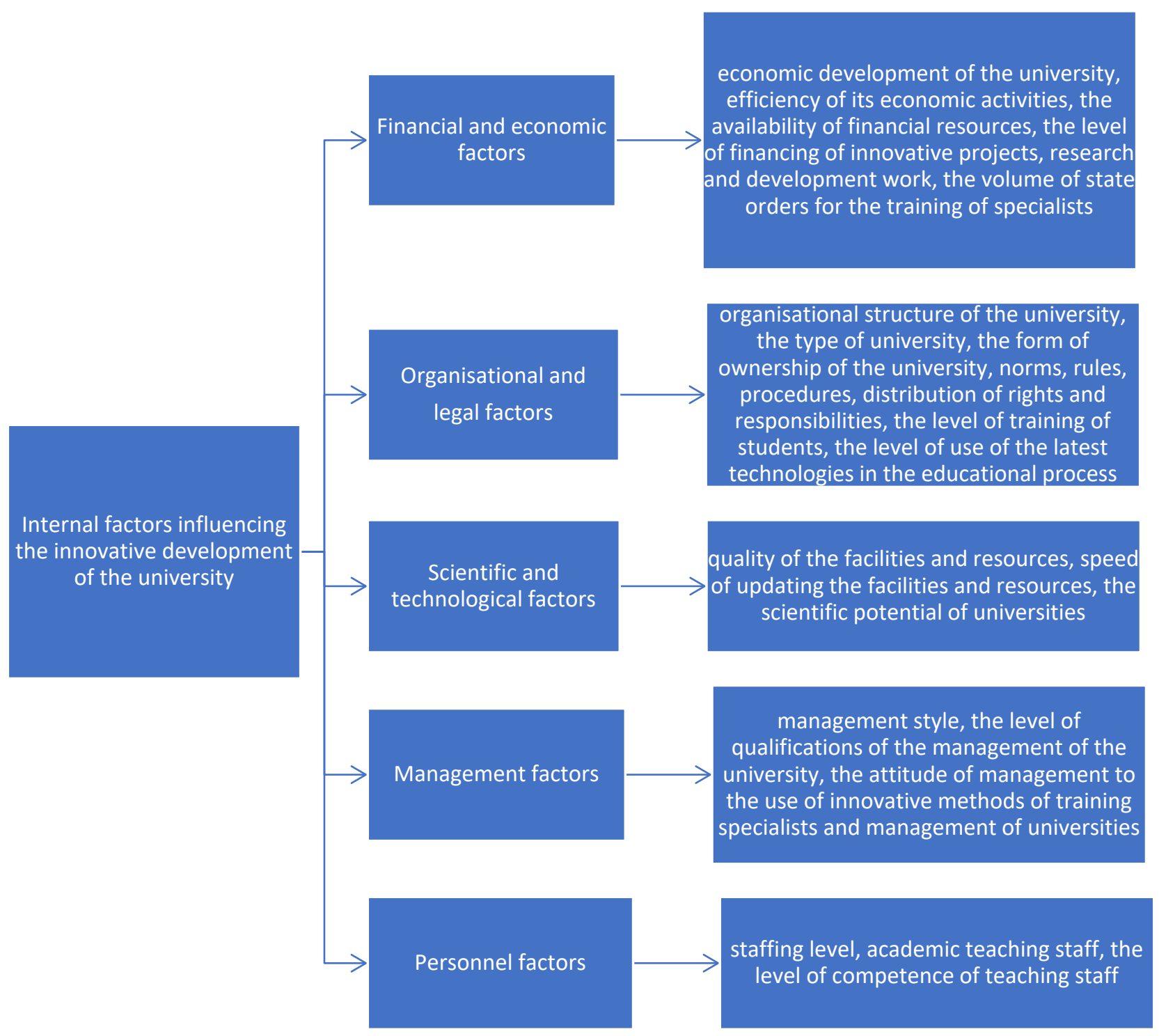

Financial and economic factors reflect the economic development of the university, the efficiency of its economic and financial activities, which characterise the availability of financial resources, etc. Financial and economic factors, depending on the degree of their impact, affect the management decision-making in different ways, that is, they promote or hinder the innovative development of universities (Table 7). Organisational and legal factors include: the type of university, the form of ownership of the university, norms, rules, procedures, distribution of rights and responsibilities, the level of training of students, the use of the latest technologies in the educational process. 
TABLE 7

INFLUENCE OF FINANCIAL AND ECONOMIC FACTORS ON THE INNOVATIVE DEVELOPMENT OF THE UNIVERSITY

\begin{tabular}{|c|c|c|c|}
\hline \multirow[t]{2}{*}{ Factor } & \multirow[t]{2}{*}{ Characteristics } & \multicolumn{2}{|c|}{$\begin{array}{c}\text { The nature of the influence of a factor on } \\
\text { the innovative development of the } \\
\text { university }\end{array}$} \\
\hline & & promotes & hinders \\
\hline \multirow{2}{*}{$\begin{array}{l}\text { Economic development of the } \\
\text { university }\end{array}$} & high & + & \\
\hline & low & & + \\
\hline \multirow{2}{*}{ Efficiency of economic activity } & efficient & + & \\
\hline & inefficient & & + \\
\hline \multirow{2}{*}{ Availability of financial resources } & high & + & \\
\hline & low & & + \\
\hline \multirow{2}{*}{$\begin{array}{l}\text { The level of financing of innovative } \\
\text { projects, research and development }\end{array}$} & high & + & \\
\hline & low & & + \\
\hline \multirow{2}{*}{$\begin{array}{l}\text { The volume of the public } \\
\text { procurement }\end{array}$} & significant & + & \\
\hline & insignificant & & + \\
\hline
\end{tabular}

Source: systematised by the author.

Higher education institutions are divided into state, municipal and private-owned universities according to the form of ownership. The form of ownership of the university determines the management structure and sources of funding, which in turn has a significant impact on the innovative development. Thus, the main source of funding for the activities of state universities is the funds of the general budget fund, which are allocated for training specialists under the state order and conducting research activities. In addition, a special fund is created, which is formed at the expense of funds received for training, retraining, advanced training of specialists, providing additional educational services under contracts with legal entities and individuals; income from renting out premises and equipment; gratuitous and charitable contributions from legal entities and individuals; income for performing scientific work under contracts with enterprises, institutions, organisations and individuals; other income in accordance with current legislation.

Financing of municipal higher educational institutions is carried out at the expense of local budgets in accordance with the Budget Code and other legal sources. And the financing of private educational institutions is carried out by their founders and from other legal sources. Another important factor among the sources of financing of universities of different forms of ownership is the targeted financing of international organisations and tuition fees for foreign students, which allows diversifying the funding sources and expands the possibilities for updating the facilities and resources and introducing innovations. By type, higher educational institutions are divided into universities, academies, institutes, and colleges. The type of institution affects its size, the level of technological development, the organisational structure, the quality of the teaching staff, the sources of funding and the direction of innovative development. Organisational and legal factors, depending on the degree of their impact, affect the management decisionmaking in different ways, that is, they promote or hinder the innovative development of universities (Table 8). 


\section{TABLE 8}

\section{INFLUENCE OF INTERNAL ORGANISATIONAL AND LEGAL FACTORS ON THE INNOVATIVE DEVELOPMENT OF THE UNIVERSITY}

\begin{tabular}{|l|c|c|c|}
\hline \multirow{2}{*}{ Factor } & \multirow{2}{*}{ Characteristics } & \multicolumn{2}{c|}{$\begin{array}{c}\text { The nature of the influence of a factor on } \\
\text { the innovative development of the } \\
\text { university }\end{array}$} \\
\cline { 3 - 4 } & & promotes & hinders \\
\hline Type of university & & + & + \\
\hline Form of ownership of the university & & + & + \\
\hline $\begin{array}{l}\text { Organisational structure of the } \\
\text { university }\end{array}$ & conservative & & + \\
\hline \multirow{2}{*}{$\begin{array}{l}\text { Norms, rules, procedures, distribution } \\
\text { of rights and responsibilities }\end{array}$} & innovative & + & + \\
\cline { 2 - 4 } The level of preparation of students & strict & & + \\
\cline { 2 - 4 } & satisfactory & + & + \\
\hline $\begin{array}{l}\text { The level of use of the latest } \\
\text { technologies in the educational } \\
\text { process }\end{array}$ & high & + & + \\
\cline { 2 - 4 } & low & & + \\
\hline
\end{tabular}

The composition of scientific and technological factors of innovative development of the university includes: the quality of the facilities and resources, the speed of updating the facilities and resources, the scientific potential of the university. The quality of facilities and resources of the university (its availability, condition and maintenance) includes educational and security facilities, furniture and equipment, computer and information base, library funds; availability of computer equipment, educational and methodological literature, provision of public catering, the possibility of using the services of the social infrastructure of universities (Abdulshaheed et al., 2019; Al-Barazanchi and Abdulshaheed, 2019; Djail et al., 2019). The scientific potential of the university includes: the scope, directions and effectiveness of research, the possibility of students' participation in scientific work, the presence of recognised scientific schools, the possibility of participating in conferences and seminars, the possibility of continuing education in postgraduate and doctoral studies. Scientific and technological factors, depending on the degree of their impact, affect management decision-making in different ways, that is, they promote or hinder the innovative development of universities (Table 9).

TABLE 9

THE INFLUENCE OF SCIENTIFIC AND TECHNOLOGICAL FACTORS ON THE INNOVATIVE DEVELOPMENT OF THE UNIVERSITY

\begin{tabular}{|l|c|c|c|}
\hline \multirow{2}{*}{ Factor } & \multirow{2}{*}{ Characteristics } & \multicolumn{2}{c|}{$\begin{array}{c}\text { The nature of the influence of a factor on } \\
\text { the innovative development of the } \\
\text { university }\end{array}$} \\
\cline { 3 - 4 } & & promotes & hinders \\
\hline \multirow{2}{*}{ Quality of the facilities and resources } & high & + & + \\
\cline { 2 - 4 } $\begin{array}{l}\text { The speed of updating the facilities } \\
\text { and resources }\end{array}$ & low & & + \\
\hline \multirow{2}{*}{ Scientific potential of the university } & high & + & + \\
\cline { 2 - 4 } & low & + & + \\
\hline
\end{tabular}


Personnel factors include the quality of the teaching staff, personal, creativity, ambition, the presence of common interests, the ability to work in a team, proper self-organisation, etc. Interpersonal relationships play an important role as a factor of influence on the innovative development of the university, since they allow the most effective use of the individual capabilities of employees. The state of the teaching staff of universities contains their scientific and pedagogical qualifications, work experience, job satisfaction and motivation for work, opportunities and areas of professional development and retraining. Personnel factors, depending on the degree of their impact, affect the management decision-making in different ways, that is, they promote or hinder the innovative development of universities (Table 10).

TABLE 10

INFLUENCE OF PERSONNEL FACTORS ON THE INNOVATIVE DEVELOPMENT OF THE UNIVERSITY

\begin{tabular}{|c|c|c|c|}
\hline \multirow[t]{2}{*}{ Factor } & \multirow[t]{2}{*}{ Characteristics } & \multicolumn{2}{|c|}{$\begin{array}{c}\text { The nature of the influence of a factor on } \\
\text { the innovative development of the } \\
\text { university }\end{array}$} \\
\hline & & promotes & hinders \\
\hline \multirow{2}{*}{ Staffing levels } & complete & + & \\
\hline & incomplete & & + \\
\hline \multirow{2}{*}{ Teaching staff } & satisfactory & + & \\
\hline & unsatisfactory & & + \\
\hline \multirow{2}{*}{ The level of competence of teachers } & high & + & \\
\hline & low & & + \\
\hline
\end{tabular}

The successful solution of the tasks related to ensuring the innovative development of the university depends on the quality and effective human resources, which is a key element of the higher education system. Staffing, the quality of training of the teaching staff and the high level of their competence will create a high-quality platform for education, increase the efficiency of research work, strengthen international cooperation and increase the competitiveness of the university. But the opposite characteristics of these factors will restrain the process of introducing innovations in the university's activities and reduce the university's ratings.

Management factors characterise the structure and effectiveness of the management system of a higher educational institution, the system of forecasting, strategic and current planning. The strategic objectives of the management are determined by the duration of the consequences, a significant impact on all areas of activity of the higher educational institution. Examples of strategic management tasks are the opening of new specialties, departments, faculties, branches, the construction of premises, the purchase of expensive educational equipment. The strategic objectives of the department also include the development and implementation of the principles and rules of remuneration and additional incentives, recruitment, and distribution of financial flows. Practical management tasks are characterised by specific binding to the execution time. This includes the preparation of annual work plans, semester schedules, repair plans, the distribution of the academic load among teachers, the printing of textbooks, etc. The operational tasks of the department are solved every day and are related to ensuring the operation of the higher educational institution. Management factors, depending on the degree of their impact, affect the management decisionmaking in different ways, that is, they promote or hinder the innovative development of universities (Table 11). 
TABLE 11

INFLUENCE OF MANAGEMENT FACTORS ON THE INNOVATIVE DEVELOPMENT OF THE UNIVERSITY

\begin{tabular}{|l|c|c|c|}
\hline \multirow{2}{*}{ Factor } & \multirow{2}{*}{ Characteristics } & \multicolumn{2}{|c|}{$\begin{array}{c}\text { The nature of the influence of a factor on } \\
\text { the innovative development of the } \\
\text { university }\end{array}$} \\
\cline { 3 - 4 } & & promotes & hinders \\
\hline \multirow{2}{*}{ Management style } & democratic & + & + \\
\cline { 2 - 4 } $\begin{array}{l}\text { University management qualification } \\
\text { level }\end{array}$ & authoritarian & & + \\
\cline { 2 - 4 } $\begin{array}{l}\text { The attitude of management to the use } \\
\text { of innovative methods of training } \\
\text { specialists and management of } \\
\text { universities }\end{array}$ & positive & + & + \\
\cline { 2 - 4 } & negative & & + \\
\hline
\end{tabular}

As shown in Table 11, management factors have a key impact on the development of higher education institutions, including the introduction of innovations in the academic, organisational, financial, and economic activities of the university. The increased influence of managerial factors on the innovative development of universities led to the adoption of a new law, which created the basis for strengthening the autonomy of universities. In particular, from now on, universities will be able to develop and implement educational programs at their own discretion, determine the forms of training and organisation of the educational process, introduce specialisations, award scientific degrees, form, reorganise and eliminate structural divisions. The university has the right to establish its own forms of financial incentives, manage income, open current and deposit accounts in banks. In other words, it is not the state that will make the decision on the distribution of funds and the income generation, but the university itself, that is, its management. That is why the management style, the level of qualification of managers, the attitude of managers to innovation affects the possibility of introducing the latest technologies in the activities of universities.

Thus, the studied external and internal factors affect both the activities of the higher institution as a whole and its innovative development and, in their entirety, are potential carriers of threats and additional opportunities of the educational institution, and should be taken into account in the strategic development programmes, in particular in the direction of adequate changes in the subsystems and elements of the innovation culture. However, it is quite difficult to take into account the influence of all factors, such a process requires significant resources, both financial and labour. Taking into account the above, based on the analysis of special economic literature, it is proposed to identify the factors that have the greatest impact, in modern economic conditions, on the components of innovative development of universities. This approach would allow making informed management decisions and focus the attention of the university management on the activity that requires significant adjustments at a given time (Table 12). 


\section{TABLE 12 \\ GROUPS OF EXTERNAL AND INTERNAL FACTORS THAT INFLUENCE THE COMPONENTS OF INNOVATIVE DEVELOPMENT OF THE UNIVERSITY}

\begin{tabular}{|c|c|c|}
\hline \multirow{2}{*}{$\begin{array}{c}\text { Components of } \\
\text { innovative development } \\
\text { of the university }\end{array}$} & \multicolumn{2}{|c|}{$\begin{array}{l}\text { Groups of factors influencing the components of innovative development } \\
\text { of the university }\end{array}$} \\
\hline & External & Internal \\
\hline Economic development & $\begin{array}{c}\text { Financial and economic factors } \\
\text { Organisational and legal factors } \\
\text { Political factors } \\
\end{array}$ & $\begin{array}{c}\text { Financial and economic factors } \\
\text { Organisational and legal factors } \\
\text { Management factors }\end{array}$ \\
\hline $\begin{array}{l}\text { Development of the } \\
\text { educational process }\end{array}$ & $\begin{array}{l}\text { Organisational and legal factors } \\
\text { Demographic factors } \\
\text { Sociocultural factors }\end{array}$ & $\begin{array}{l}\text { Organisational and legal factors } \\
\text { Management factors } \\
\text { Personnel factors }\end{array}$ \\
\hline $\begin{array}{l}\text { Development of research } \\
\text { activities }\end{array}$ & $\begin{array}{l}\text { Technological factors Financial and } \\
\text { economic factors }\end{array}$ & $\begin{array}{c}\text { Scientific and technological factors } \\
\text { Management factors } \\
\text { Personnel factors }\end{array}$ \\
\hline $\begin{array}{c}\text { Material and technical } \\
\text { development }\end{array}$ & $\begin{array}{l}\text { Technological factors Financial and } \\
\text { economic factors }\end{array}$ & $\begin{array}{l}\text { Financial and economic factors } \\
\text { Scientific and technological factors }\end{array}$ \\
\hline $\begin{array}{c}\text { Organisational } \\
\text { development }\end{array}$ & Organisational and legal factors & $\begin{array}{l}\text { Organisational and legal factors } \\
\text { Management factors }\end{array}$ \\
\hline $\begin{array}{c}\text { Human resources } \\
\text { development }\end{array}$ & $\begin{array}{l}\text { Demographic factors Sociocultural } \\
\text { factors }\end{array}$ & $\begin{array}{l}\text { Management factors Personnel } \\
\text { factors }\end{array}$ \\
\hline Information development & $\begin{array}{l}\text { Organisational and legal factors } \\
\text { Political factors }\end{array}$ & $\begin{array}{l}\text { Scientific and technological factors } \\
\text { Management factors } \\
\text { Organisational and legal factors }\end{array}$ \\
\hline Social development & Sociocultural factors & $\begin{array}{l}\text { Organisational and legal factors } \\
\text { Management factors }\end{array}$ \\
\hline $\begin{array}{l}\text { Development of } \\
\text { international relations }\end{array}$ & $\begin{array}{l}\text { Financial and economic factors } \\
\text { Organisational and legal factors } \\
\text { Political factors }\end{array}$ & $\begin{array}{l}\text { Management factors Personnel } \\
\text { factors }\end{array}$ \\
\hline Image development & $\begin{array}{l}\text { Organisational and legal factors } \\
\text { Political factors }\end{array}$ & $\begin{array}{c}\text { Financial and economic factors } \\
\text { Organisational and legal factors } \\
\text { Management factors } \\
\text { Personnel factors }\end{array}$ \\
\hline
\end{tabular}

\section{CONCLUSIONS}

The studied external and internal factors affect both the activities of the higher educational institution as a whole and its innovative development and, in their entirety, are potential carriers of threats and additional opportunities of the educational institution. The aforementioned factors should be taken into account in the strategic development programmes of the university, in particular in the line of adequate changes in the subsystems and elements of the innovation culture. However, it is quite difficult to take into account the influence of all factors, such a process requires significant resources, both financial and labour. Thus, when developing and implementing a strategy for managing the innovative development of a higher educational institution, it is advisable to take into account the influence of internal and external factors. This, undoubtedly, will facilitate the establishment of a realistic concept of the university's development, which would be based on the Ukrainian experience of educational and pedagogical activities, taking into account the trends and prospects for the development of the country's economy in general and education in particular, the needs of society, the state in education and educated citizens. 
In the course of a comparative analysis of the development of universities, the advantages and disadvantages of rating evaluation of universities were considered and the methods and results of leading rating agencies were analysed, which allows assessing the strengths and weaknesses of a particular university, contributes to the development of strategies for effective management and improvement of its activities. It was found that ratings are an effective tool for managing the education system, a means of improving the competitiveness and quality of education, on the one hand, and an important source of information about the university for applicants. Attracting as many applicants as possible is the basis for achieving the strategic goal of any higher education institution. Consequently, institutions of higher education are interested in creating a positive image, covering positive information about their activities and the quality of education in any information source, mainly in world-famous and authoritative publications. The university rankings, and especially the world rankings, are a reflection of universal recognition and popularity, which is now very much lacking in higher education institutions.

\section{REFERENCES}

Abdulshaheed, H.R., Al-Barazanchi, I., \& Binti Sidek, M.S. (2019). Survey: Benefits of integrating both wireless sensors networks and cloud computing infrastructure. Sustainable Engineering and Innovation, 1(2), 67-83.

Al-Barazanchi, I., \& Abdulshaheed, H.R. (2019). Designing a library management system for Gazi Husrev-beg library using data structure and algorithm. Heritage and Sustainable Development, $1(2), 64-71$.

Askhadullina, N.N., Vishnyakova, I.V., Aminova, G.A., Safargaliev, E.R., \& Hamatgaleeva, G.A. (2021). The search of alternative ways for professional training of future teachers to the innovationrelated risks. International Journal of Learning and Change, 13(6), 674-685.

Barlas, Y., \& Diker, V.G. (2000). A dynamic simulation game (UNIGAME) for strategic university management. Simulation and Gaming, 31(3), 331-358. https://doi.org/10.1177/104687810003100302

Cameron, C., \& Klopper, C. (2015). University lawyers: A study of legal risk, risk management and role in work integrated learning programmes. Journal of Higher Education Policy and Management, 37(3), 344-360. https://doi.org/10.1080/1360080X.2015.1034423

Chaikin, O., \& Kirieieva, E. (2020). Branch approach to sustainable development and inclusive growth: Ukraine case. Scientific Horizons, 6(91), 19-25.

Contreras, F.A.G., Hidalgo, M.E.R., Millán, A.G.L., \& Fernández, P.E.V. (2015). Agency Theory (AT): Theoretical assumptions applicable to university management. Innovar, 25(57), 11-25. https://doi.org/10.15446/innovar.v25n57.50324

Davey, B., \& Tatnall, A. (2007). Research knowledge management can be murder: University research management systems. IFIP International Federation for Information Processing, 230, 19-25. https://doi.org/10.1007/978-0-387-69312-5_3

Djail, B., Hidouci, W.K., \& Loudini, M. (2019). A filtering technique for n-way stream joins in wireless sensors networks. Revista De Direito, Estado e Telecomunicacoes, 11(1), 119-132.

Dumitrascu, O., \& Ciudin, R. (2015). Modelling factors with influence on sustainable university management. Sustainability (Switzerland), 7(2), 1483-1502. https://doi.org/10.3390/su7021483

Fiehe, S., Wagner, G., Schlanstein, P., Rosefort, C., Kopp, R., Bensberg, R., \& Arens, J. (2014). Implementation of quality management in early stages of research and development projects at a university. Biomedizinische Technik, 59(2), 135-145. https://doi.org/10.1515/bmt-2013-0085

Han, S., \& Zhong, Z. (2015). Strategy maps in university management: A comparative study. Educational Management Administration and Leadership, 43(6), 939-953. https://doi.org/10.1177/1741143214552860

Henderson, M.E., \& Knott, T.L. (2015). Starting a research data management program based in a university library. Medical Reference Services Quarterly, 34(1), 47-59. https://doi.org/10.1080/02763869.2015.986783 
Howells, J.R.L., Karataş-Özkan, M., Yavuz, Ç., \& Atiq, M. (2014). University management and organisational change: A dynamic institutional perspective. Cambridge Journal of Regions, Economy and Society, 7(2), 251-270. https://doi.org/10.1093/cjres/rsu005

Karimova, B.S., \& Zhetpeisova, N.O. (2020). On innovative pedagogical technologies and training methods. International Journal of Learning and Change, 12(1), 15-24.

Kirkland, J. (2008). University research management: An emerging profession in the developing world. Technology Analysis and Strategic Management, 20(6), 717-726. https://doi.org/10.1080/09537320802426416

Kok, S.K., Douglas, A., \& McClelland, B. (2009). University management and globalisation: An examination of the changing dynamics in UK universities. International Journal of Knowledge, Culture and Change Management, 9(3), 71-84. https://doi.org/10.18848/14479524/cgp/v09i03/49714

Lafuente-Ruiz-De-Sabando, A., Forcada, J., \& Zorilla, P. (2018). The marketing orientation as a university management philosophy: A framework to guide its application. Cuadernos de Gestion, 18(2), 37-58. https://doi.org/10.5295/cdg.150576al

Leischnig, A., \& Geigenmüller, A. (2020). Examining alliance management capabilities in universityindustry collaboration. Journal of Technology Transfer, 45(1), 9-30. https://doi.org/10.1007/s10961-018-9671-7

Mirķe, E., Kašparová, E., \& Cakula, S. (2019). Adults' readiness for online learning in the czech republic and latvia (digital competence as a result of ICT education policy and information society development strategy). Periodicals of Engineering and Natural Sciences, 7(1), 205-215.

Mokhlis, C.E., Elmortada, A., Sbihi, M., \& Mokhlis, K. (2019). The impact of ISO 9001 quality management on organizational learning and innovation: Proposal for a conceptual framework. Periodicals of Engineering and Natural Sciences, 7(2), 944-951.

Pellow, A., \& Wilson, T.D. (1993). The management information requirements of heads of university departments: A critical success factors approach. Journal of Information Science, 19(6), 425-437. https://doi.org/10.1177/016555159301900602

Sánchez-Moreno, M., \& Toussaint-Banville, M. (2017). Dilemmas in university academic management. Profesorado, 21(3), 201-218.

Serhiienko, M.S., Liutyi, V.M., \& Wilson, M. (2021). Experience in implementing distance learning technologies in an international context. Scientific Bulletin of Mukachevo State University. Series "Pedagogy and Psychology", 7(3), 39-46.

Sharrock, G. (2012). Four management agendas for Australian universities. Journal of Higher Education Policy and Management, 34(3), 323-337. https://doi.org/10.1080/1360080X.2012.678728

Valmorbida, S.M.I., Ensslin, S.R., Ensslin, L., \& Ripoll-Feliu, V.M. (2015). University management with focus on multicriteria performance evaluation: Illustration in the Brazilian context. Journal Globalisation, Competitiveness and Governability, 9(2), 61-75. https://doi.org/10.3232/GCG.2015.V9.N2.03

Veer Ramjeawon, P., \& Rowley, J. (2020). Enablers and barriers to knowledge management in universities: perspectives from South Africa and Mauritius. Aslib Journal of Information Management, 72(5), 745-764. https://doi.org/10.1108/AJIM-12-2019-0362

Yonezawa, Y. (2018). Management of internationalisation in Japanese universities: Towards the development of collaborative relationship between academic and administrative staff. Higher Education Forum, 15, 39-62.

Zabalandikoetxea, S.U., \& Merino, J.D.G. (2013). Factors dependent on university management as determinants of student performance: A multivariate analysis. Revista de Educacion, 361, 456489. https://doi.org/10.4438/1988-592X-RE-2013-361-229 